\title{
The politics of governing cities, infrastructures and resource flows: spaces of reproduction or reconfiguration?
}

\section{Mike Hodson, Simon Marvin, Salford}

\section{Introduction}

The fundamental preoccupation of this paper is to develop a theoretical and conceptual understanding of the role of space and politics in governing relationships between cities, infrastructures and resource flows. In doing this a view of cities as dynamic, experimental social spaces, constituted by coalitions of institutions and actors, is articulated where relationships between space and infrastructure are represented and mobilized in ways which either seek to re-enforce or undermine existing relationships. Cities are not only promoted as central to economic growth strategies but are also often centres of expanding human populations and sites of the consumption of resources and production of emissions and wastes. The critical mediators of urban ecological, economic and social reproduction are critical infrastructure networks, particularly energy, water, waste and transportation.

Increasingly, the extent to which urban and regional strategies are able to demonstrate that they hold together economic, ecological and social equity goals are additionally being questioned by a series of wider geopolitical pressures. Patterns and flows of resources, the organisation of their production and consumption, are being challenged through what is increasingly being characterised as resource constraint - the «peaking» of oil and gas, energy and water security and the environmental problems created by waste and landfill - and also through the spatial enablements and constraints afforded by the cascading of internationally and nationally negotiated climate change priorities, targets and associated carbon regulations. These developments are creating pressures on the ways in which large socio-technical infrastructure systems (HuGHEs 1987), many of which were initially designed in the late nineteenth and early twentieth centuries, and resource flows are organised in western contexts.

Yet, this raises fundamental issues for understanding the governance and priorities of the city, the governance and priorities of socio-technical infrastructure systems and the relationship between the two. This is not naturally produced but is the consequence of governance coalitions that have the potential to embody the variable participation of social interests - from urban government, through utilities, regulators, business, consumers, citizens and so on. This is a political configuration. How this is organized will shed light on «the way things are» in the relationship between city and infrastructure. The emerging ecological and economic pressures present challenges to the ways in which city and critical infrastructure are organized. Whether these pressures result in a strengthening of the existing configuration or its transformation is, thus, a political and spatial struggle. It is this spatial politics of governing cities, infrastructure and resource flows with which this paper is primarily concerned.

In doing this the paper has four sections. First, it theorises and conceptualises the role of space and politics in governing relationships between cities, infrastructures and resource flows. Second, it reviews an emerging set of new pressures to the ways in which cities, infrastructure and resource flows are organised under conditions of neo-liberal urbanism. Third, it constructs a theoretical and conceptual approach to reflect on the re-organisation of city, infrastructure and resource flows as predicated on tensions between transformative reconfiguration and obduracy from historically produced coalitions. Finally, key conclusions are presented.

\section{Space, politics and governing cities, critical infrastructure and resource flows}

Conventional thinking about the relationships between cities, infrastructures and resource flows primarily addresses the impact of infrastructures (or a lack of them) on places, the provision of networked services for places, network failures in relation to places, shortages or uncertainties in resource provision and so on. Frequently the plans, images, maps and schemes that represent relationships between cities and different networks do so, partly out of necessity, in ways that simplify and reduce it to a fixed absolute space (HARVEY 2006).

This article is a summary version and reproduction of: Hodson, M. \& S. Marvin (2010): World cities and climate change: producing urban ecological security; Part I: Theory, concepts and issues. - Maidenhead: Open University Press. 
Yet, these ways of thinking about such relationships say little about why they are organised in the way they are and how the representation of absolute space is relationally and relatively produced (HARVEY 2006; MASSEY 2005). The politics, struggle, social interests and processes of negotiation underpinning not only such representations but the realities they seek to represent are lost or obscured. The point is that the relationship between cities, infrastructure and the organisation of resources that are produced, consumed and flow through cities is not unproblematic and is deeply political. Governing this politics involves interactions and negotiations of a range of institutional and social interests and understanding the constitution of such governance coalitions and their capabilities to act. Such interactions are informed by and informing of relationships between cities, infrastructures and resource flows. The politics of these interactions are mediated by a struggle between maintaining things the way things are, finding out why they are that way, and, at another level, thinking about how they might be reconceived.

Representational space (MASSEY 2005) allows views of complex and deeply political relationships between infrastructures, resource flows and places to be articulated and framed in highly exclusionary ways. Often this results in an equation of space and representation where both the spatial and meaning are fixed, closed, static and discrete. In doing so space obliterates processual time to the privileging of instants. It also excludes a multiplicity of co-existing narratives and potential narratives. Space as representation in this way is representative of a view of place that already «exists», and through representation is re-enforced, rather than constitutive of what space and place can become. In this way, fixity in representations of space frames an ideological closure through imagining, defining and attributing particular meaning to places (MASSEY 2005).

Seeing space as actively, relationally and relatively produced (HARVEY 2006; MASSEY 2005) means the possibility to understand attempts to define and categorise cities not only in relation to existing and absolute representations of the city but also through the ways in which the governance field of interrelationships of institutions and social interests seek to re-constitute an identity for the city. This is not to view place as reducible to a narrow localism but to see it as produced through coalitions of multi-level governance interests, institutions, pressures, forms of knowledge, technologies and resources in the widest sense of that term. The issue is how this is done and this will be addressed later in the paper.

Not only are spaces relationally produced but they are understood in the way they are organised relative to each other. Spaces are produced relationally and, in the competitive context of neo-liberal globalisation, coalitions of interests have engaged in a «race» vis-àvis each other to represent categorisations and identities of success. This has led to attempts to replicate what are represented as successful cities and places and has seen the fixes developed in particular spaces and places represented as replicable between contexts. Relative space allows a puncturing of the veneer of the unitary spatial representation of the city and the uncovering of the multiplicity of varying spatial infrastructural configurations within cities. The result is the exposure of the oxymoron of seeking to replicate spatial distinctiveness.

Relationships between different notions of space are significant. The ideological closure that spatial fixity produces can be opened up through thinking relationally and relatively about space and place; it can create possibilities for multiple spatial imaginations to flourish in ways which deny fixity and acknowledge the dynamism involved in making and re-making space. This is the tension between a narrow politics, usually of protecting the status quo, and a transformative understanding of space. It is related to the process of becoming rather than of staking a narrow claim for meaning and categorisation as to what already exists. Space is not a container for the representation and persuasive mobilisation of the desirability of already constituted identities, nor is it completely closed but it is a locus for constituting a view of what the city could and should become. In this way the understanding of space presented here is critical for further exploring urban infrastructural processes.

Viewing each of the component aspects of this triumvirate - cities, infrastructure and resource flows - not as absolute spaces or containers but through their relational and their relative production vis-à-vis other spaces provides the basis of a helpful way of thinking about the mutual and political production of cities, infrastructure networks and resource flows. This view sees the city as relationally and dynamically constituted from networks of asymmetric and unfolding relationships that include and exclude. These are asymmetric in the sense of the local social interests who bring different forms of financial resources, expertise and influence to networks but also in respect of wider multi-level governance relationships where the relationship of national state and/or supranational political institutions to territorial social networks are structured in highly variable ways. To put this another way, different levels of authority work on the same territory that itself is subject to constant re-interpretation. Not only is territory subject to constant re-interpretation from multiple levels of authority and positions but it is also central to the struggle and negotiation for clas- 
sification. Coalitions of multiple social interests - the «who» of the city with often varying expectations seek to shape its future orientation and what it should become.

\section{3 «New» pressures on the organisation of cities, infrastructures and resource flows}

The organisation of cities, infrastructures and resource flows and the relationships between them are complex, deeply political and rooted in ideological struggle. The reproduction of these relationships, that since the $1980 \mathrm{~s}$ have in the west been mediated through a neo-liberal discourse of competition, innovation, liberalisation and so on, is increasingly encountering a further set of emerging pressures. Market-based economic activity and growth remains a fundamental mediator of relationships between places and infrastructure but increasingly serious consideration in organising these relationships is being paid to the challenges posed by climate change, both in terms of anticipating its «impacts» and also the strategic direction of national state actors in regulating and disciplining spaces (HoDson \& MARVIN 2010). Furthermore, the geopolitics of oil, natural gas and water and also waste management questions again with both geopolitical and more regionalised consequences - are contributing to a wider set of pressures and debates around resource management and, in particular the ways in which reconfiguring systems and the relationships between systems and places can effectively address resource constraints.

Increasingly the language of threats, risks, dependencies, vulnerabilities, impacts and security are being mobilised to confront the current organisations of cities and infrastructures in ways which encompass issues related to resource constraint and climate change. More tangibly this includes in respect of energy, for example, a dependency of large parts of the western world on the geopolitics of the supply of oil and natural gas from volatile regions and in particular the - contested - peaking of global oil production. A critical consequence of this is pressure for many, particularly, western economies, to diversify the type and sources of energy production. A critical issue is the timeframe - likely to stretch over a couple of decades - of reconfiguring domestic energy supplies.

Not only is time an issue in respect of how long it would take to reconfigure energy systems based on fossil fuels (oil, natural gas and coal) but so it is also in respect of constraints of resources - when oil and natural gas reserves, for example, have peaked is a critical issue as is when the impacts of climate change are forecast to be felt. This is not only important in respect of assumptions and scenarios but also in terms of varying per- ceptions as to the availability of resources and the consequences of climate change. Arguments around the scarcity of resources are not altogether new. Debates around the earth's limits to growth from the early 1970s (MEADows et al. 1972), are now being revisited.

Recent debates around resource flows are taking place in a context of significant demographic shifts - including a growing global population, an ageing western population - increasing urbanisation and the spread of urbanisation processes to the newly developing economies of China and India in particular, deforestation, energy constraints, the loss of biodiversity, the impacts of climate change for global populations through flood risk, extremes of temperature and water shortages. Economic growth and the geographical spread of modernised and industrialised notions of economic activity and associated energy use to newly developing countries could mean that the world will use twice as much energy in 2035 as today and that by as soon as 2020 electricity demand could be 70 per cent higher than today (RoBERTs 2004). Yet the terms of the debate on resource futures rarely question in any fundamental way the levels of consumer activities within western economies. The organisation of resource flows is predicated on such a view of what constitutes progress and attempts to respond to the challenges posed by resource constraints and climate change need to be seen in light of the socio-political organisation of the huge metalogistical systems (LukE 2003) that make fossil fuel economies possible.

New pressures are, of course, mediated through the power relationships of existing urban governance coalitions - organised across multiple levels and in particular influenced by the ways in which national state actors view places - and also through existing sociotechnical infrastructure systems. This is particularly important as it says much about latent capacities at an urban scale to organise the relationships between cities and infrastructure mediated through these new priorities. It also says much about the ways in which national state actors are able to discipline state spaces through cascading down regulatory measures and the extent to which urban coalitions are able to effectively respond to this or even prefigure such measures. These pressures also encourage newer players to enter both urban governance and infrastructure system fields and, in some cases, working between and bridging the two. In this respect these new pressures are mediated through the path dependencies of existing systems and the transformative aspirations of both new players and entrepreneurial institutions and actors within existing coalitions.

The challenge this poses relates to governing the (re-) organisation of production-consumption relation- 
ships; or, to put it another way, of re-situating the city in a space of circulation and the way such a process is governed (by whom, promoting what values, with what effects and so on). Yet this is to be done in an age of the decentring of power in which governments have contributed to their own ungovernability.

\section{Re-producing and re-positioning space, place and infrastructure}

This part of the paper develops a theoretical and conceptual understanding of the governance of space, of resource flows and socio-technical infrastructure systems and the dynamic and ongoing ways in which this shapes places and vice versa. The tensions between what things are and what they can become is pronounced in the face of new ecological pressures - climate change and resource constraint - and the ways in which these are incorporated into the relational spaces that re-produce the relationships between cities, infrastructures and resource flows. Yet, if responses to these pressures are not natural, what are the social interests involved in promoting the status quo or transformation? How can responses to these new pressures be understood?

These two questions underpin a concern with not only understanding processes of transformation but also addressing constraints on and urban contexts of transformation. New pressures are likely to bring responses from governance coalitions that includes both established actors within urban and infrastructural fields and also new actors and social interests. This includes the multiplicity of relationships that constitute the city, but also that produce socio-technical energy, water, waster and transportation systems - which particularly in contexts of privatisation and liberalisation can be best understood as encompassing a range of social interests and actors. The development of urban strategies is thus likely to include well established interests in the fields of both urban governance and the governance of socio-technical systems and new entrepreneurial actors working between the two. A relational understanding opens up space as political. In the process of becoming and constituting new identities spaces, places and re-imagining the communities and economies of cities (ANDERSON 1991; CAMERON \& Palan 2004),

«[r]ather than an explicit conflict over political aims what we have now is a confrontation between imaginations of the city» (MASSEY 2005: 157).

The power of representations are in their search for certainty, abstraction and universalism in the relationships between cities, socio-technical infrastructures and resource flows and they contribute fundamen- tally to attempts to achieve (often temporary) closure or stabilisation (BIJKER et al. 1987). There are, thus, two intricately linked issues here. The first relates to trying to gain greater understanding of the processes of constructing representations. The second is in trying to understand the ways in which such representations frame a partial, privileged understanding of relationships between cities, socio-technical infrastructures and resource flows.

What they are and what they can become is related to the issue of the relational, knowledge and financial capacity that can be mobilised into a capability to act. The tension here is between closing down and fixing views of place through privileging representational space and obscuring the relational and relative spaces of its production and the opening up of relational space to re-think relative and representational space. At the extremes it is a tension between the status quo, its obduracy and transformation, between narrowly constituted private space and a more broadly conceived participatory public space and between inclusion and exclusion. It is useful here to invoke the idea of relational and relative space as fields (BouRdieu 1993).

Field allows thinking about relational space as constituting the capacity to act (that is latent action or possibility) and the capability to act (which is the mobilisation of capacity). Thinking in this way helps understand the lattice of governance arrangements, the multiplicity of different actors, public and private, at different scales, supranational, national, city-regional, organisational, with often differing motivations, forms of knowledge, financial resources and aspirations who take a view of, make claims of and act on the relationship between city, infrastructure and resource flows. This may be seen as

«a field of multiple actors, trajectories, stories with their own energies - which may mingle in harmony, collide, even annihilate each other» (MASSEY 2007:22).

This requires understanding institutional interrelationships of knowledge, financial resources and capabilities in relation to and as a response to new pressures and, in this respect, the entrance of other influences (often national state actors) into the field of relationships that constitute urban infrastructures and resource flows. Understanding the responses to new pressures requires an acknowledgment of interrelationships across scales of political activity - both as historically constituted and how they might be reconfigured.

Spaces of reproduction and radical reconfiguration. Whilst notions such as durability in thinking about institutions may be fruitful in relatively stable contexts of reproduction, with a resultant degree of institutional lock-in, how can institutional interrelationships, where 
transformation and innovation are being encouraged, be understood? In contrast to structurally-informed durability in social relations (the position outlined above) relationships between cities, infrastructures and resources can helpfully be understood as sociotechnical (Hughes 1987). Existing institutional frameworks that produce cities - by definition - will often be predicated on an institutional reproduction that is relatively habitual. In the face of new pressures this can create tensions between the obduracy of existing institutional interrelationships and the possibilities of socio-technical transformation. This requires exploring the intersections of institutional durability and socio-technical agency.

The emphasis on the durability of social relations highlights the importance of historically generated relationships, practices and knowledge and in many ways equates with what has been called lock-in. It also suggests that understanding the transformative potential of building new institutional interrelationships needs to take account of the ways in which those who become involved in responding to the new pressures, from particular institutional settings, are disposed to act in particular ways which have been informed by those settings. This is as dispositions are informed by social structures (Bourdieu 2000); social structures which are relational in the sense that they are bound up with the field of institutional positions (BouRdiEU 1993).

Yet historically informed institutional interrelationships, which may have been cultivated and appropriate for an earlier period of urban growth and/or infrastructural development may offer inappropriate social structures for those engaged in contemporary responses to new pressures. An issue is to what extent those engaged in socio-technical infrastructural innovation are able to reflect upon these social structures, assess the possibilities for and limits upon transformation and then decide on the shape subsequent action should take (BOHMAN 1999).

The historically structured relationships that produce a categorisation of the relationship between city, infrastructures and resource flows may at oner extreme habitually and unreflexively re-produce themselves - what can be called closed spaces of reproduction - whilst at the other extreme they may be radically transformed through the interpretation and reflection of the latent capacity that constitutes the field to form a very different capability to act - in open spaces of radical reconfiguration. The possibility for individuals and institutions - e.g. key players, consultants - to position themselves relates to the types and stock of relevant knowledge, financial resources and social networks they hold.
Bringing together, for example, technical forms of knowledge, regulatory knowledge and localised cultural knowledge requires the work of mediation or brokering between different and often disparate social interests from institutional contexts (see FISCHER 2003). In creating relational space in this dynamic way the boundaries that are often fixed and closed in representational space have the potential to be opened up. It is in this respect that institutional structure and transformative agency come together.

The ability to re-position themselves, for those officials, policymakers, industrialists, utilities, regulators and so on who become involved in urban infrastructural innovation, suggests some (differential) capability to act in more innovative ways within existing cultural institutional constraints. This more reflexive move allows actors «within» an urban context the possibility to reflect on cultural constraints and to seek where appropriate to innovatively re-position themselves in terms of the new relationships that constitute a response to emerging new pressures. In this view urban infrastructural innovation is culturally negotiated and open to interpretative flexibility (BIJKER et al. 1987). The political issue is how certain configurations win out in the vast array of innovative possibilities or how heterogeneous urban infrastructure networks come to be assembled.

\section{Conclusion}

This article has examined the basis of relationships between cities, infrastructures and resource flows. It has demonstrated that they are politically produced through spatially configured coalitions of interrelationships of institutions and social interests that are dynamic and always in the process of becoming even if that process is punctuated by temporary fixes. Cities are increasingly confronted by a new set of pressures posed by peak oil and the wider geopolitics of oil and natural gas, water constraint and stress, the environmental consequences of landfill waste, the carbon and methane emissions associated with contemporary modes of economic organisation and the consequences that this poses for urban areas.

These pressures to reconfigure relationships between cities, infrastructure and resources take place in relation to existing spaces and places where obduracy and transformation structure local struggles. This matters in that it brings to the forefront of this debate the issue of whether responses are formulated through a status quo of social interests or new social interests and which of these - or new combinations between them - is preferable. That is to say that not only are forms of urban infrastructures and resource flows mediated 
through neo-liberal forms of economic activity but also through climate change, ecologically extended notions of security, resource constraint, spatial regulation, national state priorities and so on but these discourses may be appropriated and are mobilised differentially by coalitions in different spaces. This will be partly due to the relative power of social interests to impose their expectations of what urban infrastructures and the resources that flow through them are for but also in certain urban contexts the lack of power to mobilise alternative expectations.

Not only is the issue one of the power to define urban infrastructure and resource futures in relation to particular cities but also the power of particular urban coalitions to produce a view of a city's relationship to infrastructure that positions it more favourably relative to other cities. In this respect the competitive race of urban entrepreneurialism is being opened up to a new struggle as to what the urban eco-entrepreneurial race would look like. Inherent in such struggles are the ways in which cities and socio-technical infrastructures are organised and governed and views of and value judgments of the ways in which relationships between society and technology, urban and nature, economy and ecology, and scales of governance are mediated through this and re-made.

This, as the paper demonstrated, requires ways of not only understanding these new pressures but also in thinking about the relationships between them and strategic urban responses that seek to imagine a new urban future from the positions of existing relationships and contexts; that is the connection of a strategic response of a different urban future from existing and historically produced contexts and requires addressing the relationships between obdurate urbanisms, the potential for transformation and the dynamism inherent between these two broad positions.

\section{References}

Anderson, B. (1991): Imagined communities: reflections on the origin and spread of nationalism. London: Verso.

Bijker, W.E., Hughes, T.P. \& T. Pinch (eds) (1987): The social construction of technological systems. - Cambridge: MIT Press.

Bohman, J. (1999): Practical reason and cultural constraint. - In: SHUSTERMAN, R. (ed.): Bourdieu: a critical reader. - Oxford: Blackwell: 129-152.

Bourdieu, P. (1993): Sociology in question. - London: Sage.

Bourdieu, P. (2000): Pascalian meditations. Translated by R. Nice. - Cambridge: Polity Press.

Cameron, A. \& R. Palan (2004): The imagined economies of globalization. - London: Sage.
FIscher, F. (2003): Reframing public policy. Discursive politics and deliberative practices. - New York: Oxford University Press.

Harvey, D. (2006): Spaces of global capitalism. Towards a Theory of Uneven Geographical Development. - London: Verso.

Hodson, M. \& S. Marvin (2010): World cities and climate change: producing urban ecological security. Maidenhead: Open University Press.

Hughes, T.P. (1987): The evolution of large technological systems. -In: BiJker, W.E., Hughes, T.P. \& T.J. PINCH (eds): The social construction of technological systems: new directions in the sociology and history of technology. - Cambridge: MIT Press: 17-50.

LukE, T. (2003): Codes, collectivities, and commodities: rethinking global cities as megalogistical spaces. - In: Krause, L. \& P. Petro (eds): Global cities: cinema, architecture, and urbanism in a digital age. - New Brunswick, N.J.: Rutgers University Press.

Massey, D. (2005): For space. - London: Sage

Massey, D. (2007): World city. - Cambridge: Polity Press.

Meadows, D.H., Meadows, D.L., Randers, J. \& W.W. BeHrens (1972): Limits to growth. - New York: Potomac Associates.

Roberts, P. (2004): The end of oil. - New York: Houghton Mifflin.

\section{Abstract: The politics of governing cities, infrastruc- tures and resource flows: spaces of reproduction or reconfiguration?}

This paper develops a theoretical and conceptual understanding of the role of space and politics in governing relationships between cities, critical energy, water, waste and transportation infrastructures and resource flows. It presents a view of cities as dynamic, experimental social spaces underpinned by infrastructural unevenness with variable provision of and access to resource flows. An emerging set of new pressures to the ways in which cities, infrastructure and resource flows are organised under conditions of neo-liberal urbanism is reviewed. The paper then reflects theoretically and conceptually on the ways in which these pressures can be appropriated in terms of the re-organisation of city, networked infrastructure and resource flows as predicated on tensions between transformative reconfiguration and obduracy from historically produced social and institutional coalitions.

Keywords: space, politics, infrastructure, experiments

\section{Zusammenfassung: Stadt-, Infrastruktur- und Res- sourcenpolitik: Räume der Reproduktion oder der Rekonfiguration?}

Der Artikel entwickelt einen theoretischen und konzeptionellen Zugang zum Raum und zur Politik sowie 
zu ihrer jeweiligen Rolle in der Beziehung von Städten, kritischen Energie-, Wasser-, Abfall- und Transportinfrastrukturen und den entsprechenden Ressourcen. Dabei geht der Artikel davon aus, dass Städte dynamische, experimentelle und soziale Räume sind, die mit infrastruktureller Ungleichheit und variablen Zugangsmöglichkeiten zu Ressourcen ausgestattet sind. Zunächst skizziert der Artikel die neuen Herausforderungen, die der neoliberale Urbanismus im Bezug auf die Organisation von Städten, Infrastrukturen und Ressourcen bedeutet. Davon ausgehend wird theoretisch und konzeptionell darüber reflektiert, wie diesen Herausforderungen im Rahmen einer Reorganisation von Städten, Infrastrukturen und Ressourcen begegnet werden kann, die sich im Spannungsfeld von transformativen Rekonfigurationen und historisch generierten sozialen und institutionellen Koalitionen bewegen muss.

Schlüsselwörter: Raum, Politik, Infrastruktur, Experimente

\section{Résumé: Les politiques de gestion des villes, des infrastructures et des ressources: espaces de repro- duction ou de reconfiguration ?}

Cet article développe une réflexion théorique et conceptuelle sur le rôle de l'espace et des politiques mises en cuvre en matière de relations entre les villes, les infrastructures critiques liées à l'énergie, à l'eau, aux déchets et aux transports, et les ressources. Il considère les villes comme des espaces sociaux dynamiques et expérimentaux, dans lesquels l'offre et l'accès aux ressources est inégal. L'article passe tout d'abord en revue les nouvelles pressions qui s'exercent sur les villes, les infrastructures et les ressources dans le contexte de l'urbanisme néolibéral. Il présente ensuite, du point de vue théorique et conceptuel, comment ces pressions peuvent être réappropriées en matière de réorganisation urbaine, d'infrastructures et de ressources, en se fondant sur les tensions entre les reconfigurations contemporaines et les coalitions socio-institutionnelles qui se sont développées au cours du temps.

Mots-clés: espace, politiques, infrastructures, expérimentation

Dr. Mike Hodson, Prof. Dr. Simon Marvin, SURF Centre (The Centre for Sustainable Urban and Regional Futures), University of Salford, 113-115 Portland Street, Manchester, M1 6DW, United Kingdom. e-mail:

M.Hodson@salford.ac.uk

S.Marvin@salford.ac.uk

Manuskripteingang/received/manuscrit reçu le 3.1.2011

Annahme zum Druck/accepted for publication/accepté pour publication: 27.6 .2011 